$$
15 \text { (sin) }
$$

\title{
A hazai turizmusstatisztika története
}

Probáld Ákos,

a Központi Statisztikai Hivatal ny. főosztályvezetője

E-mail: probaldakos@gmail.com
Magyarország gazdaság- és társadalomtörténetében a turizmus évtizedek óta jelen van, és az ezredforduló óta egyre nagyobb szerepet játszik nem csupán a külgazdaság fejlődésében, de a lakosság életminőségének, életszínvonalának, boldogságérzetének javításában is. A 2017 októberében elfogadott turizmusfejlesztési stratégia elörevetíti, hogy a turizmus a következő évtizedekben is egyik kiemelt területe lesz a gazdaságnak és a jóllétnek, amihez a statisztika a maga eszközeivel szükségszerüen hozzájárulhat. A jövő statisztikusgenerációinak a turisztikai statisztikával foglalkozó elödök több évtizedes tapasztalatára, a múlt megismerésére, a felhalmozott tudástökére érdemes és kell is építenie. A tanulmány elsősorban a Központi Statisztikai Hivatal adatgyüjtésein, empirikus kutatásain keresztül mutatja be a turizmusstatisztika fejlődéstörténetét, de kitér a hivatalos statisztikai szolgálat másik szereplője, a Belügyminisztérium adatgyüjtő-tevékenységére is.

TÁRGYSZÓ:

Turizmusstatisztika.

Statisztikatörténet.

DOI: 10.20311/stat2018.06.hu0610 
A szakirodalom, így a statisztika is csak az ezredforduló kezdete óta használja a turizmus szót, korábban - feltehetően a német nyelvböl tükörfordított „fremdenverkehr" - idegenforgalom kifejezést alkalmazták. Az 1867-es kiegyezéskor, valamint az önálló magyar statisztikai szolgálat és hivatal létrejöttét követően nem sokkal, 1885-ben már napirendre került az idegenforgalmi statisztika szükségessége. Valószínűleg nem véletlenül, hiszen az utazás távolabbi országokba, földrészekre évszázadok óta - már az egyiptomi, a római, a görög és később a reneszánsz kultúrák virágzásának idején - jelen volt, ha erről nem is maradtak fenn statisztikai értékü feljegyzések, akkor is tudható, hogy az utazás mindig is fontos tényezője a társadalmaknak. A turizmus mint nemzetközileg is elfogadott statisztikai fogalom hosszabb idő alatt alakult ki. A Népszövetség már 1937-ben tett javaslatot a „,nemzetközi turista" fogalom használatára, majd az ENSZ (Egyesült Nemzetek Szervezete) Statisztikai Bizottsága 1963-ban a római konferencián tett olyan javaslatot, amit 1968-ban fogadtak el. Az ennek megfelelő hazai gyakorlat Lengyel Márton [2004] ma is érvényes definíciója szerint ,a turizmus a szokásos környezetükből szabadidő eltöltése, üzleti vagy egyéb célból más helyre utazó és ott kevesebb, mint egy évig tartózkodó személyek tevékenysége".

A turizmus és folyamatos nyomon követésének fontosságára Magyarországon elöször Thirring Gusztáv hívta fel nyomatékosabban a figyelmet a Városok Lapjában (Thirring [1927a] 145. old.): ,... az idegenforgalmi statisztika ... vidéki városainkban eddig teljesen hiányzik. Pedig kétségtelen, hogy az idegenforgalom céltudatos fejlesztésére sok-sok hasznos útbaigazítást adhatna, ha eddigi idegenforgalmunk nagyságát, az érkező idegenek eredetét, ott tartózkodásuk tartamát pontosan ismernők. Ily statisztika megteremtése semmi különösebb nehézségekkel nem járna; a székesfővárosi idegenforgalmi statisztika mintájára igen könnyen lehetne a vidéki városokat is a szállodákban amúgy is köteles nyilvántartásoknak a statisztika részére való értékesítésére szorítani ... az idegenforgalmi szervezetek világosan látnák, hogy tulajdonképpen hogy is állunk városaink idegenforgalmával, mennyi a belföldi, mennyi a külföldi idegen, honnan jön utóbbi, s mely irányban kifejtendő propaganda kecsegtetne sikerrel...". Budapest idegenforgalmáról Kolacsek András [1970] közölt az 1885 és 1896 közötti évekről adatokat, igaz, forrásmegjelölés nélkül. Valószínü, hogy a forrás a „Jelentés Budapest székesfőváros Idegenforgalmi Hivatalának 1928. évi müködéséről” címü dokumentum, mely azt említi, hogy „...1885 óta, amióta az idegenforgalmi statisztikai adatgyüjtés megkezdödött...”. Tehát már ekkor létezett igaz csupán a fővárosra korlátozottan - törvényben nem szabályozott idegenforgalmi adatgyüjtés (Székesfơvárosi Házinyomda [1928]). 
„...A statisztikai hivatalok munkásságának eredményei kiadványaikban jutnak kifejezésre...” (Thirring [1927a]). Ilyen például a „Budapest Székesfőváros Statisztikai és Közigazgatási Évkönyve” című kiadvány, amely 1912-től jelent meg, és már 1906-tól(!) 138 magyar városról (tehát Trianon előttről) - töredékesen ugyan, de közölte a „megszállt idegenek” számát havonkénti és a külföldiek esetében ,államok szerinti" bontásban.

Elöször 1927-ben került sor arra, hogy az idegenforgalmi hivatal kiszámítsa és publikálja Budapest külföldi idegenforgalmának gazdasági eredményeit (Budapest Székesföváros Idegenforgalmi Hivatala [1928]). A hivatal jelentései 1929-töl kezdve már az országos eredményekre is kiterjedtek.

Az 1930-as évektől Markos Béla fejtett ki kiemelkedő tevékenységet az idegenforgalmi kutatásokban. „Jelentés Budapest 1942. évi idegenforgalmáról és az 1942. év idegenforgalmának gazdasági eredményeiröl" című írásában többek között arról számolt be, hogy ismert ugyan a szállodák és panziók vendégforgalma havonta, külföldi, belföldi érkező vendégek részletezésben, ám a bevételeket, illetve a „mellék kiadásokat" rendszeresen becsülni kellett. A magánszállások forgalmára és bevételére vonatkozó adatokat szintén becsüléssel állították elő, így állapították meg a „gazdasági értéket”. Markos így ír az adatgyűjtés nehézségeiről: „,...E téren azonban igen nehéz feladat elött állunk ... amíg ugyanis Budapest idegenforgalmára vonatkozóan a Székesfőváros Statisztikai Hivatalának világviszonylatban is elsőrendủ és példaadó adatgyüjtése a kiindulásra megfelelő alapot ad számításainkhoz, addig Magyarország vidéki idegenforgalmáról egységes idegenforgalmi statisztikával mindeddig még nem rendelkezünk" (Markos [1927]).

A második, 1897. évi XXXV. statisztikai törvény 3. §-a egy munkaterv készítését rendeli az adott évi adatgyüjtések felsorolásával a Magyar Királyi Statisztikai Hivatal számára, ám ez a munkaterv tételesen még nem említi az idegenforgalmat. A „munkaterv" lényegét, az adatgyüjtések felsorolását az azóta eltelt 120 évben született további öt statisztikai törvény maradéktalanul megőrizte, különböző megnevezésekkel illette. Az 1993. évi XLVI. tv. vezette be az OSAP-ot (Országos Statisztikai Adatgyüjtési [ma Adatfelvételi] Program), amely azóta tartalmaz idegenforgalom fejezetet, felsorolva az idegenforgalommal (turizmussal) szorosan összefüggö adatgyüjtéseket.

A második világháborút követő 8-10 évben az idegenforgalom nem volt a statisztika homlokterében. A KSH (Központi Statisztikai Hivatal) „Magyarország népesedése, 1957” című évkönyvének (a későbbi demográfiai évkönyv) „Külső vándorlások" fejezetében 8 táblázat foglalkozott a Magyarországra érkező és a külföldre utazó magyarok számával, 3-4 változó és ezek kombinációja (hónap, állampolgárság, határállomás, irány) szerint ( $K S H$ [1958b]). Az „idegenforgalom” szó csak két táblázat címében, ott is zárójelben jelent meg. A Magyar Statisztikai Évkönyv ugyanerről az évröl megjelent kiadásában hasonló terjedelmet szentelt az idegenforgalomnak $(K S H[1958 \mathrm{~d}])$. 
A 1950-es évek végére tehető a hivatalos idegenforgalmi statisztika szakirodalmának kialakulása. Kolacsek András és Markos Béla „Az idegenforgalmi statisztika időszerü problémái” című cikkükben így írnak: „Csak a statisztika tud reális képet adni ... az előttünk álló feladatokról és lehetőségekről. ...a statisztika adataira támaszkodnak azok a számítások, amelyek ... [a] külföldi idegenforgalom népgazdasági értékét kívánják megállapítani." A hazai gyakorlatban használt határstatisztikáról ezt írják: „,...annak hibája, hogy nem ad képet az idegenforgalomnak az ország területén való megoszlásáról ...., nem adja meg az idegenek tartózkodási napjainak számát.” A lakosság idegenforgalma is az érdeklődésük középpontjába került: „...Azonban a szociális és gazdasági szempontból fontos belföldi idegenforgalom helyes fejlesztése sem képzelhető el az idevágó statisztikai adatok ismerete nélkül." (Kolacsek-Markos [1958])

A Havi Statisztikai Közlemények 1959. évi 4. számának már volt idegenforgalom fejezete. Ez az első olyan hivatalos magyar idegenforgalmi adat-összeállítás, amely képet adott a külföldi idegenforgalom megoszlásáról az ország fontosabb területein, adatokat közölt annak jelleg (beutazó, átutazó) szerinti rétegződéséről, és tájékoztatott a külföldiek által Magyarországon eltöltött tartózkodási napok számáról is. Ugyanekkor közölték - 1949 után - első ízben a magyar szállodai vendégforgalom és tartózkodás adatait. Kolacsek és Markos - mint kiemelkedő idegenforgalmi szakemberek - ezeket „nagy segítségként” értékelték, de a „további fejlődés” érdekében már egyéb igényeket is megfogalmaztak, ,az idegenforgalom külföldi eredetủ bevételeinek meghatározásával" is kísérleteztek (Kolacsek-Markos [1959]).

Kovács László és Takács János az 1966-ban kiadott „Az idegenforgalom alakulása és fejlődése (1945-1965)" címü könyvükben - némi túlzással ugyan - azt hangsúlyozták, hogy ,....nincs olyan területe az idegenforgalomnak, amely statisztikailag ne kerülne megfigyelésre.” (Kovács-Takács [1966]) Ekkor már világosan látszott, hogy az idegenforgalom sem nélkülözheti a rendszerbe foglalt folyamatos statisztikát: „....az idegenforgalmi statisztika nagy szerepet játszik az idegenforgalmi munka irányításában, ... vezetői döntések megalapozásában ... a jövő irányának meghatározása ... az idegenforgalom jelenségeinek tudományos elemzése ... az összefüggések feltárása megbízható, teljes és pontos statisztikai adatszolgáltatás nélkül alig lehetséges." (Kovács-Takács [1966])

\section{Statisztikai megfigyelések}

A KSH az 1950-es évektől alapvetően kétirányú adatgyüjtést végzett: ún. határstatisztikait és vendégforgalmit; utóbbi akkor már az ország összes elszállásolási 
üzemét felölelte. A határstatisztikai adatgyüjtést lényegében a Belügyminisztérium Határőrsége végezte, a szálláshelyektől maga a hivatal gyüjtötte az adatokat.

\subsection{Határstatisztika}

A KSH adatgyüjtési rendszerében nem is szereplö határstatisztika 1949-töl 1957ig lényegében a Belügyminisztérium felügyelete alá tartozó Határőrségnek az egyes határállomások személyzetének szolgálatszervezését támogató nyilvántartásából, a határállomásonként készített és a Határőrség központjába havonta továbbított „,személy és járműforgalmi jelentéséből" állt. ${ }^{1}$ Ekkor még teljes volt a vízumkényszer, az országhatár átlépése külföldieknek és magyar állampolgároknak mindkét irányba szigorú ellenőrzés mellett volt csak lehetséges. A határt átlépő külföldieket „aktív idegenforgalomként”, a külföldre utazó magyar állampolgárokat, sajátos szóhasználattal, „passzív idegenforgalomként” említették a korabeli publikációk. Az 1954-ig évi néhány 10 ezres utasforgalom többnyire hivatalos, kevésbé üdülési célú volt, és nagyrészt a szocialista országokból származott, illetve a külföldre utazó magyarok részéről is azokba irányult. Más-más vízum volt érvényes az ,átutazókra” - nekik 48 óra tartózkodási időt engedélyeztek - és a „beutazókra”. Ezek alapján állapították meg a határt átlépő külföldi állampolgárok (ez utóbbiakat állampolgárság szerinti részletezésben) számát, a be- és kilépő forgalom szerint egyaránt. Az említett jelentésben ugyanígy nyilvántartották a határt átlépő (vasúti, közúti, vízi, légi) járművek számát is. A be- és a kiutazók száma ekkor még tartalmazta a be- és kivándorlókét. (1956 tekintetében az illegálisan utazókat - menekülteket - is.) Ezeket az adatokat vette át a KSH havonkénti rendszerességgel és közölte egyre bővülő részletezettséggel, eleinte a demográfiai évkönyvekben, majd a statisztikai évkönyvekben, kezdetben „külső vándorlás”, egy idő után zárójelben „idegenforgalom” címen. Ha úgy tetszik ez egyfajta előzménye volt az adminisztratív nyilvántartások ma előtérbe kerülő, statisztikai célú felhasználásának.

Az ennél bővebb információkat - a tartózkodás célja, helye, időtartama - tartalmazó idegenforgalmi statisztikát a KSH csak 1958-tól szervezte meg különböző „statisztikai lapok” alkalmazásával (Fenyő [1966]). Más-más statisztikai lap volt érvényes a ki- és a bevándorlók, a szocialista országokból érkezők és az odautazó magyarok, a nem szocialista országokba utazó és onnan visszautazó magyarok részére. A kérdések kiterjedtek néhány olyan változó, mint a motiváció (rokonlátogatás, üdülés, hivatalos út, átutazás) megismerésére, de a statisztikai lapból meg lehetett tudni a magyarországi, illetve külföldön tartózkodás hosszát és a használt közlekedési eszközt is.

\footnotetext{
${ }^{1}$ Ez az adatgyüjtés mind a mai napig él, az OSAP Belügyminisztérium által kezelt fejezetében.
} 
A Belügyminisztérium felügyelete alá tartozó KEOKH (Külföldieket Ellenőrző Országos Központi Hivatal) a nem szocialista országokból érkező külföldiek számára a vízumokhoz csatolt ún. be-, illetve kiutazólapokat tette kötelezővé. A kiutazólapok egy példányát a KEOKH saját ellenőrzési munkája mellett, idegenforgalmi statisztikai célú feldolgozásra átadta a KSH-nak. Ettől kezdve a felsorolt változók szerint bővült a publikált határstatisztikai adatok köre, bár egyre súlyosabb gondokat okozott, hogy a határállomások jelentéséből és a statisztikai lapok feldolgozásából származó adatok eltértek egymástól. Az utazók számára vonatkozó, a nagyságrendeket távolról sem érintő eltérő adat az elkallódott vagy feldolgozásra alkalmatlan statisztikai lapokból adódott, ám ez nem befolyásolta az eloszlásokra, átlagos tartózkodási időre vonatkoztatható becslések hitelességét. A hatvanas évek közepétől a fokozatosan érvényesített utazási könnyítések következtében jelentősen megugrott az utasforgalom, a bizonylatok kezelése, összegyüjtése, továbbítása (postázása), tárolása, feldolgozhatósága már egyre nagyobb kihívást jelentett a statisztikai szolgálat számára. Ezen a KSH 1972-től úgy igyekezett úrrá lenni, hogy a nem szocialista országokból érkező statisztikai lapokból szisztematikus kiválasztással - minden $k$-adik lap felhasználásával a hivatalban mintát vett, a $k$ meghatározása pedig - a szezonalitás jelentős hatása miatt - havonta történt. A szocialista országokra vonatkozó szisztematikus mintavételt a határállomásokon a Határőrség végezte, mivel az utasok és járművek egyszerü számlálása a határállomásokon megmaradt, rendelkezésre állt tehát a mintavételi keret. Ez nagyságrendekkel csökkentette a szükséges adatlapok számát, és kezelhetővé tette a feldolgozásra szánt kérdőív mennyiségét, továbbá nem veszélyeztette a publikált adatok frissességét.

Az utasforgalom adatait (viszonylag) pontosnak lehetett tekinteni, hiszen a teljes körü számlálás következtében a mintavételi keret a jelentésekből származott, az utasforgalom változói alapján készült teljeskörüsített adatok viszont becslések eredményei voltak (és azok ma is). A szisztematikus mintavételt követően, a teljesörüsítés során a becslések országcsoportokra, illetve az összes külföldi idegenforgalomban érintettre vonatkozóan utólagos rétegzéssel készültek. Ezekhez hibahatárok is tartoztak, amelyeket a KSH sokáig éves idegenforgalmi kiadványainak mellékleteiben közölt. Napjainkban ez már nem gyakorlat.

Az évek során az eljárások rendre finomodtak, „karbantartásukra” is sor került, alkalmazkodva a változó gazdasági és politikai körülményekhez, valamint a turizmussá átlényegülö, folyamatosan fejlődő idegenforgalomhoz (KSH [1983], Besenyei-Probáld [1975], Móritzné Gyenge-Probáld [1981]). A szakterület fejlődése, bővülése gazdaságossági kérdéseket is felvetett, nevezetesen, hogy mennyibe is kerül a költségvetésnek ez a statisztikai információ. A KSH és a Határőrség évről évre kötött megállapodásaikban részletesen rögzítették a két szervezet határstatisztikai adatgyüjtésben vállalt feladatait.

$\mathrm{Az}$ eddigiekben bemutatott határforgalmi statisztika lényegében Magyarország európai uniós, illetve schengeni egyezményhez való csatlakozásáig alapvetően nem 
változott. Az egyezmény azonban a határstatisztikában is alapvető fordulatot hozott, hiszen az ún. belső határokon megszünt az ott áthaladó személy- (és jármü-) forgalom ellenörzése. Ez azt jelentette, hogy az osztrák, szlovák, szlovén határszakaszokról nem állt rendelkezésre a határt átlépők számáról információ, vagyis a mintavételi keret az ukrán, román, horvát és szerb határszakaszokon maradt meg. A hiányzó adatokat egy sokváltozós modell elkészítésével állította és állítja elő ma is a KSH. Ebben, az adott határszakaszra ismert múlt hosszú idősorai, a külső határokról rendelkezésre álló friss információk, a szálláshely-statisztikák naprakész adatai, valamint a hazánkkal határos uniós, schengeni egyezményt alkalmazó országokkal öszszekötő fontosabb közutak, határok közelében a forgalomban érintett, nagyságuk alapján kijelölt pontokon végrehajtott forgalomszámlálások adatai képezik az inputot; az output pedig a fontosabb partnerországokból származó becsült utasforgalom.

Napjainkban számlálóbiztosok végzik a forgalomszámlálást az év kijelölt napjain, az azonnali adattovábbítást lehetővé tevő PDA-eszközökkel (personal digital assistant - digitális személyi asszisztens) rögzítik az áthaladó jármúvek szemrevételezéssel megállapított számát. A schengeni belső határszakaszokra a forgalom nagysága alapján kiválasztott határátkelőkre vonatkozóan történik a megfigyelés. A közeli jövő olyan további technológiai változást hozhat, amelyben a forgalmi adatok a határokhoz közeli közutakon elhelyezett forgalomfigyelő kameráktól származnak majd folyamatosan (az év minden napjára, 24 órán keresztül), a mostaninál lényegesen kisebb torzítással.

Az utasok kikérdezését 25 közúti átkelőhely közelében és a Budapest Liszt Ferenc Nemzetközi Repülőtéren, egy naptári év előre rögzített napjain, a napszakokat is meghatározva, ugyancsak PDA-eszközökkel, több nyelven beszélő kérdezőbiztosok segítségével végzik. Az egykori „statisztikai lapokat” kiváltó számítógépes kérdőívek kitöltése, valamint tárolása is ellenőrzötten történik, majd tartalmuk a központi adatbázisba automatikusan feltöltődik, ahol további ellenőrzés mellett feldolgozzák azokat. Az alkalmazott eljárás részletes, módszertani leírása, metainformációi a hivatal honlapján jelenleg korlátozott tartalommal érhető csak el, frissítése a közeli jövőben várható (https://www.ksh.hu/docs/hun/info/02osap/onk/2003/d152003.pdf).

A kérdezési program elsősorban az évek hosszú során változó kormányzati szervek (Belkereskedelmi Minisztérium, Országos Idegenforgalmi Tanács, Országos Idegenforgalmi Bizottság, Országos Turisztikai Bizottság, Nemzeti Turisztikai Bizottság, Magyar Turisztikai Ügynökség) által kiemelt felhasználói igények (vállalkozói, pénzügyi, kormányzati, civilszféra) minél jobb kielégítése érdekében folyamatosan bővült, és amelyből már tudható:

- az utazók (részletes, ma már 24 elemből álló) motivációja;

- az egyénileg vagy csoportosan megvalósult utazás ténye;

- a Magyarországon eltöltött idő; 
- az igénybe vett szálláshely;

- az utazás során igénybe vett közlekedési eszköz;

- az országon belül felkeresett régió;

- a Magyarországon elköltött összegek (fogyasztás) és azok részletei (struktúrája);

- a fizetőeszköz-használat módja (készpénz, bankkártya).

Az mindig is fontos kérdés volt, hogy a kérdezési program hossza, az interjúk időtartama mikor éri el azt a kritikus, türelmiküszöb-értéket, ami már veszélyezteti a megvalósíthatóságot. Mennyi energia (és pénz) befektetésével lehet elérni, hogy a nem kevés számú válaszmegtagadás mellett értékelhető mennyiségü interjú készülhessen. Az utóbbi öt-hat év átlagában évi 40-45 ezer interjú készült a külföldiekkel és 10-12 ezer a külföldre utazó magyarokkal. Ezek az adatok azért megnyugtatók, mert a fontosabb változókombinációk által definiálható becslések megbízhatóságát erösítik.

A lakosság külföldi utazásait az előbbiekben bemutatotthoz nagyon hasonló módon és tartalommal végrehajtott adatgyüjtés vizsgálja.

Nagyon fontos felhasználási területe az adatgyüjtéseknek, hogy ma már ezek alapján készülnek a külföldiek magyarországi és a külföldre utazó magyarok külföldön megvalósult költekezéseire, fogyasztására vonatkozó becslések, melyek - a külkereskedelmi adatbázisok és a nemzeti számlák alapján végrehajtott korrekciók után az MNB-hez (Magyar Nemzeti Bank) kerülve - beépülnek Magyarország fizetési mérlegébe. A hivatal a nemzeti számlák felhasználási oldalán - nemzeti fogyasztás, hazai fogyasztás - veszi számba az adatgyüjtés eredményeit. A határstatisztikai adatgyüjtések egyben fontos pillérei a turizmus szatellitszámla felhasználói oldala összeállításának is.

Meg kell jegyezni, hogy hasonló adatgyüjtési eljárást viszonylag kevés ország alkalmaz. A magyar gyakorlat, mint „best practice” (legjobb gyakorlat) leginkább a spanyol mintát követte, de - az ezredforduló elején - tanulmányozta a francia próbálkozásokat is. A meglehetősen hosszú múlttal rendelkező osztrák, német, olasz vagy éppen svájci hivatalos statisztikai rendszerek nem vállalkoznak ilyen szofisztikált rendszerek müködtetésére, inkább hagyatkoznak gazdaságkutató-intézetek munkáira. A skandináv országok némelyike (leginkább a norvég hivatal) is próbálkozott, főleg a határ menti napi ingázások vizsgálatára. Az Eurostatnak (Európai Unió Statisztikai Hivatala) is voltak az 1990-es évek közepén a napi ingázás mérésre, a határ menti „bevásárlóturizmus” (shuttle trade) vizsgálatára tett, de eredménytelennek bizonyult programkísérletei. 


\subsection{Szálláshely-statisztika és a lakosság becsült üdülővagyona}

A határstatisztikánál sokkal hosszabb múltra tekint vissza a nemzetközi gyakorlatban is szinte mindenhol alkalmazott szálláshely-statisztika. A statisztikai adatgyüjtés a szállodák vendégforgalmáról Budapesten - nem sokkal az önálló statisztikai hivatal megszületése után - már 1885-ben, lényegében önkéntes feljegyzéssel megkezdődött. A Budapest Székesfőváros Statisztikai Hivatala - több, kevesebb korláttal - egészen 1949-ig gyüjtött és közölt adatokat a budapesti szálláshelyek idegenforgalmáról.

„...Budapest főváros ... statisztikai hivatala 1874. évben kezdette meg a munkálataihoz szükséges adatokban szélesebb körben való gyüjtését. Az e célra szolgáló 110 különböző mintát a statisztikai bizottmány tárgyalásai alapján a föváros tanácsa 1872 február 29-én 6277/1. sz. határozatával hagyta jóvá ... Tanácsi határozatokkal szabályozta és szervezte a főváros a statisztikai szolgálatnak azon ágait, melyekhez a főváros saját hivatalai vagy intézetei szolgáltatták a szükséges nyersanyagot ... Ez az adatszolgáltatási rendszer nagyon labilis volt..." mondja Thirring (Thirring [1927b]).

Az idegenforgalmi statisztika alapjait a fogadó, vendéglő, kávéház és kávémérési iparoknak Budapest székesfőváros területén való gyakorlásáról szóló 802/1907kgy. sz. szabályrendelet rakta le: „Ez a szabályrendelet kötelezte a föváros területén fennálló összes szállodákat, vendégfogadókat és penziókat, hogy a bennük megszállott idegenekről - a főváros tanácsa által megállapított mintán - a statisztikai hivatalhoz minden hó 5-ig kimutatásokat küldjenek be. A föváros tanácsa 110.124/1909 sz. határozatával állapította meg az ezen felvételre szolgáló mintát, amely a megszállott idegenek érkezésének és elutazásának napját, az érkezett személyek számát és származási helyét (rendes lakásuk országát és községét) kutatja. ...A statisztikai hivatal müködésének univerzálisnak kell lennie. Ez az univerzitás a begyülő rengeteg anyagnak bizonyos csoportosítását teszi szükségessé, amelyet 7 alosztályba foglalhatunk össze.” (Thirring [1927b])

E szerint az idegenforgalom begyüjtött adatait a 4. gazdasági statisztika osztályban, a „közlekedés” címszónál kellett felsorolni.

Budapest Székesfőváros Törvényhatósági Bizottságának közgyülése 1916. május 24-én 603. sz. 32.539/1916-XV. számú előterjesztésében indítványozta Budapest Székesfőváros Idegenforgalmi Hivatalának létesítését, amely 1943-ig állította össze éves jelentéseit. A hivatal elsőként végzett becslésszerủ számításokat annak kiderítésére, hogy milyen gazdasági hasznot hajt Budapestnek az idegenforgalom. Arra vonatkozóan is megkíséreltek becsléseket készíteni, hogy mekkora lehetett a lakásokon, magánszálláshelyeken megszálló belföldi és külföldi vendégek száma.

Markos Béla [1943] írásában arról számol be, hogy Budapest első nagy idegenforgalmi eseménye az 1885. évi, törvénybe iktatott „Általános Kiállítás” volt. Ebből 
az alkalomból - az első budapesti idegenforgalmi statisztikai adatfelvétel tanulsága szerint - „...102 252 idegen látogatott Budapestre, közöttük 66775 Magyarországról 35477 pedig külföldröl”".

A törvényhatóság azután 1888. március 11-én bizottságot küldött ki az idegenforgalom érdekében teendő különböző intézkedések megtételére. A bizottság határozatainak végrehajtására a Budapest Székesfőváros Statisztikai Hivatala keretében egy irodát szerveztek Körösy József megbízásával. Az a körülmény hogy a bizottság végrehajtó irodája a Budapest Székesfőváros Statisztikai Hivatalában müködött, azzal az előnnyel járt, hogy az illetékesek figyelme már korán ráterelődött az idegenforgalmi statisztika fontosságára. Körösy megbízást adott az 1885. esztendöre vonatkozó statisztikák elkészítésére, majd 1888-tól kezdődően évről évre folytatódott az idegenforgalmi statisztikai adatok publikálása. Budapest ezzel megindította azt a szakszerü idegenforgalmi statisztikai adatgyüjtést, amely hosszú ideig, lényegében (kisebb szünettel 1949 és 1958 között) 1958-ig egyedüli volt az országban. A hivatal a szállodákban és panziókban megszállt belföldiekről és külföldiekről, az érkezők és a tartózkodási napok számának országonkénti és havonkénti részletezésével folyamatosan, azonos elvek alapján állított össze statisztikát, amelyet a „Statisztikai Havi Füzetek" címü kiadványban jelentetett meg. Hivatalos idegenforgalmi statisztika azonban országos szinten nem volt, Budapest mellett csak Sopron igyekezett azonos elvek alapján adatokat gyüjteni. A Budapest Székesfőváros Idegenforgalmi Hivatala, majd később az Idegenforgalmi Kutató Intézet ${ }^{2}$ évröl évre bekérte ugyan a legfontosabb vidéki települések idegenforgalmának számadatait, ez az anyag azonban az adatgyüjtési módszerekben mutatkozó eltérésekre tekintettel sem területi, sem időbeni összehasonlításra nem volt alkalmas.

Annyi bizonyos, hogy idegenforgalmi statisztikai adatgyüjtés hiányában - különös tekintettel az egyes vidéki települések forgalmáról közölt statisztikák időnkénti szakszerütlen összeállítására - az első világháborút megelőző és a két világháború közötti években a budapesti statisztika az egyetlen olyan forrás, amelynek adataiból az egész magyar idegenforgalom alakulására következtethetünk.

A második világháborút követően Sárdi Endre [1958] írt először átfogó elemzést a magyarországi szállodákról és üdülőkről: , ,...a külföldi és a belföldi vendégek elhelyezésére első sorban a szállodák és az üdülök jönnek számításba....az üdülők beutalás útján vehetők igénybe...Az üdültetés a Szakszervezetek Országos Tanácsa (SZOT) üdülőházaiban vagy a vállalatok, intézmények, hivatalok saját kezelésében lévő (zömmel a korábban államosított szállodákban és egyéb erre alkalmas, kisajátított épületekben) üdülőkben történik...” Az idézett cikk alapja egy 1957. évi szabályozásnak megfelelő idegenforgalmi szálláshelyek (szállodák fogadók, panziók, turistaházak és üdü-

\footnotetext{
${ }^{2}$ Először 1948 és 1949 között az IBUSZ (Idegenforgalmi, Beszerzési, Utazási és Szállítási Rt.) egyik szervezeti egységeként, majd rövid ideig az Országos Idegenforgalmi Tanács keretében müködött.
} 
lők) műszaki adottságait feltáró összeírás volt, amelyből csupán a szálláshelyek kapacitásáról és felszereltségéről lehet információt találni, forgalmukról nem. Néhány évvel később Markos-Kolacsek [1961] könyvükben „Idegenforgalmi lehetőségek és eredmények" címmel már önálló fejezetet szenteltek a statisztikának.

Már az 1950-es évek végén a magánszálláshelyek felé irányult a figyelem: „,..a magánlakásokat, a fizetővendéglátást közvetítő idegenforgalmi szerveket, illetve a rendkívüli táborok vezetöit kell adatszolgáltatásra kötelezni ... az üdültetések szerves és igen fontos részét alkotják az idegenforgalomnak ... ennélfogva a statisztikának feltétlenül ki kell terjednie az üdülök forgalmára is." '(Kolacsek-Markos [1958]). A második világháború után az 1980-as évekig a belföldi turizmus „társadalmasításának" fontos eleme volt a szakszervezeti, munkahelyi üdültetés - és így ennek statisztikai kezelése is - ami, ha nem is teljesen, de lényegében eltünt, vagy jelentösen elsorvadt.

A turizmus kínálati oldalának legmarkánsabb elemét jelentő szálláshelyszolgáltató-hálózatának müszaki, technikai, felszereltségi állapotának, a szolgáltatás sokszínűségének bemutatását 1957 és 1987 között 6-10 évenként önálló adatfelvételek és az ezekből született kiadványok szolgálták.

A Magyar Királyi Statisztikai Hivatal [1938] gondozásában született egy kiadvány, amely 462 községet kezelt üdülőhelyként és 596 fürdőintézmény (beleértve a 337 fövenyfürdőt is) mellett, 1714 szálloda, vendégfogadó és panzió összeírásáról számolt be. Ez az adatgyüjtés bár szerény volt, kitért olyan adottságokra mint a villanyvilágítás, valamint a vízvezeték-, fürdőszoba-, fütés- vagy telefonellátottság, és megkülönböztetett kisebb (10 szobánál kevesebb), illetve nagyobb (10 szobánál több) létesítményeket is.

A felvételi programok a szállodák, kempingek és nyaralóházak, üdülők és egyéb üdülési szálláshelyek, valamint a fizetővendéglátás (ez a szálláshely típus 1957-től 2008-ig létezett ezzel a megnevezéssel) esetében részben közös, részben a szálláshely típusának megfelelő saját, egyedi programblokkal rendelkeztek. A kérdések feltárták a szálláshelyek korát, üzemméretét, kapacitását, műszaki felszereltségét, elhelyezkedési jellemzöit, nyújtott szolgáltatásait, eszközértékét, beruházási, felújitási, karbantartási ráfordításait, a létesítményben vagy közelében müködö üzletek és vendéglátóhelyek számát, a foglalkoztatottak részletes adatait stb.

Az adatgyüjtések eredményeiröl a KSH önálló kiadványokban számolt be ( $K S H$ [1958c], [1965], [1970], [1980], [1989]). Ezekre az volt jellemző, hogy az összeírt adatoknak csak egy részét mutatták be. Az eredeti kérdőívek és feldolgozási táblák a KSH levéltárába kerültek, illetve megsemmisültek, így az értékes adatok publikációkban nem hasznosított részletei ma már nem rekonstruálhatók. Azóta ilyen felvételek nem készültek, sem a kereskedelmi és egyéb (magán), sem a nonprofit szálláshelyflotta müszaki állapotát bemutató összeállítás nem valósult meg. A civil szakmai szervezetek közül a Magyar Szállodák és Éttermek Szövetsége rendelkezik egy adat- 
bázissal az európai szinten harmonizált szállodai tanúsító védjegyrendszerbe (Hotel Stars Union) önkéntesen bejelentkezett, tehát minősített szállodákról (az országos szállodaflotta nagyjából 60 százalékáról), de összefoglaló részletes értékelés, adatösszeállítás ezekről sem készült.

Az idegenforgalmi szálláshelyek kapacitás- és teljesítményadatait felölelő teljes körü, országos adatgyüjtés az 1950-es években kezdődött, de a Magyar Statisztikai Évkönyvekben 1955-ig csak ,szakszervezeti üdültetés” címen jelentek meg összefoglaló adatok. Az 1960. évi évkönyv azután már „közhasználatú szálláshelyek” és „üdülés” címü fejezeteket is tartalmazott. A Statisztikai Időszaki Közlemények évközben nem tettek közzé szálláshelyekre vonatkozó adatokat, bár gyüjtöttek ilyeneket. Ezek közlése csak 1961-töl váltak rendszeressé.

Az adatgyüjtéseket az ún. kereskedelmi szálláshelyekre vonatkozóan az 1950-es évek óta végrehajtja a KSH, címük, érvényességük tartománya, gyakoriságuk, tartalmuk az idők folyamán sokszor változott, lefedettségük azonban mindvégig teljes körü volt, és az napjainkban is.

Az 1973. évi statisztikai törvény foglalta rendszerbe és nevesítette az adatgyüjtéseket, ennek dokumentálására a hivatal évente jelentette meg „A KSH ... évi adatgyűjtési rendszere" című kiadványát. A szálláshelyekről gyűjtött és közölt adatkörök a szálláshelyek kapacitásától (egység, szoba, férőhely) a vendégforgalomig (belföldi és külföldi bontásban: vendégek, vendégéjszakák száma, illetve részletezése küldő országonként) terjedt. Az eleinte „közhasználatú szálláshelyek” elnevezés később „kereskedelmi szálláshelyekre” változott, az adatkörök pedig fokozatosan bővültek a bevételekkel, majd egyes szolgáltatások (például a vendéglátás) elérhetóségével, egy ideig a szállodák áraival, bevezetését követően (2011) a Széchenyi Pihenőkártyaelfogadás adataival. Az árakat (átlagárakat) - amelyek addig a szálláshelyek ún. listaárai voltak - a 2000-es évek elejétől már számította a KSH a bevételek és a hónap során kiadott szobák adataiból. A kereskedelmi szálláshelyeket - melyeket elnevezésükből adódóan bárki igénybe vehetett - szállástípusonként (szállodák, kempingek, nyaralóházak, turistaszállások, ifjúsági szállások, fizetővendéglátás) különböztették meg. A szállodákat és kempingeket, nyaralóházakat szolgáltatási színvonaluknak megfelelően rendeletek szintjén sorolták osztályokba.

A kereskedelmi szálláshelyeket havonta mérték fel a „Jelentés a kereskedelmi szálláshelyekröl" címü adatgyüjtés keretében, amely először 1970-ben jelent meg ezzel az elnevezéssel a KSH adatgyüjtési rendszerében, és változatlanul a mai napig érvényben van. A kereskedelmi szálláshelyek müködését az évek során számos alkalommal szabályozták a vonatkozó belkereskedelmi minisztériumi, később kormányrendeletek, amelyek rendre foglalkoztak a különböző szálláshelyek típusainak meghatározásával, osztályba sorolásával, továbbá müködésük sokszor szerteágazó és bürokratikus feltételrendszerével. A hivatalos statisztika ezt mindenkor igyekezett követni, annyi azonban bizonyos, hogy ezek a gyakori szabályváltozások az adatok 
hosszú idősorainak összehasonlítását nehezítették, olykor (különösen a szállodának definiált szálláshelycsoportban) látszólag alig magyarázható töréseket okoztak.

Az ún. fizetővendéglátás - külön kategóriaként - lényegében magánszemélyek lakásaikban, nyaralóikban végzett, külön engedélyhez, majd a 2000-es években már csupán bejelentéshez kötött tevékenysége volt. Ezek a rendszerváltozás elött, az akkoriban még létező tanácsok felügyelete alatt levő megyei idegenforgalmi hivatalok, egyes kiemelt országos vendéglátó vállalatok és az utazási irodák által szervezetten, utána pedig önszerveződő módon müködtek. A KSH az ebben a keretben lebonyolódó vendégforgalmat külön adatgyüjtéssel „Jelentés a fizetővendéglátásról” címmel, havonta követte. Ahogyan a magánszemélyek vállalkozó kedve élénkült és szálláshelyszolgáltatótevékenysége terebélyesedett, úgy szembesült egyre nehezebb helyzettel a statisztika is. Az adatgyüjtés gyakorisága előbb negyedévesre, majd félévesre változott. A tevékenységi engedélyek nyilvántartását egy kormányrendelet az önkormányzatokra bízta, a statisztika pedig kétlépcsős adatgyüjtést vezetett be. A KSH az adatszolgáltatást az önkormányzatok számára teljeskörúen (manapság évről évre változó számú, körülbelül 1200-1500 település érintett) írta elő, amelyek a szálláshelyszolgáltató-tevékenységet végző több tízezer magánszemélytől gyüjtötték és gyüjtik be ma is az adatokat. Az adatgyüjtés 1998-tól 2009-ig „Jelentés a magánszálláshelyekröl” elnevezésű volt, majd miután egy 2009. évi kormányrendelet ezeket a magánszálláshelyeket „egyéb szálláshelyként” azonosította, 2010-től „Jelentés az üzleti célú egyéb szálláshelyekről” címüre változott, és azóta így jelenik meg az OSAP-ban. Ez az adatgyűjtés a kétlépcsős rendszer bevezetése óta csupán éves gyakoriságú, és a kapacitásadatokra (szállásadók, szoba, férőhely), valamint a vendégforgalom (vendég és éjszaka) külföldi, belföldi bontására terjed ki. Elsősorban a kormányzati adatfelhasználók és a civilszervezetek részéről évről évre felmerül az igény az évközi és részletesebb külföldi adatok előállítására. Az adatszolgáltatók adminisztratív terhelésének csökkentése, a gyakoriság bővítése és az adatmélység részletesebbé tétele ellen szól. Az adatgyüjtés első lépcsőjében érintett vendéglátók online bekapcsolása egy adatgyüjtési rendszerbe akkor válhat aktuálissá, ha a lakosság internetes ellátottsága és digitális kultúrája - első sorban a kistelepüléseken lényegesen javul. A regionális adatok iránti fokozott igény pedig a reprezentativitás (a mintavételes adatgyűjtés) alkalmazását nehezítené meg.

Az idegenforgalmi statisztika keretében rövid ideig (1982 és 1989 között) érvényben volt a „Jelentés az üzembe helyezett szállodai beruházásokról” címü, meglehetősen kiterjedt tartalommal rendelkező adatgyüjtés, ez azonban beépült az általános beruházási statisztikába, viszont kikerült a KSH (akkori) Kereskedelmi és közlekedési statisztikai főosztályának felelősségi köréből. Ennek ellenére a turizmussal foglalkozó éves összefoglaló kiadványok rendszeresen tartalmaztak szállodai beruházási adatokat.

A 2007 és 2010 közötti időszakban életben volt a „Szállodai gyorsjelentés” címü havi gyakoriságú adatgyüjtés, amely a legnagyobb forgalmú szállodákra és csupán

Statisztikai Szemle, 96. évfolụam 6. szóm 610-640. oldal 
azok néhány kulcsmutatójára (a vendégforgalom globális mutatóira, a bevételekre, az árakra és a foglaltságra) terjedt ki. Az adatgyüjtés bevezetését a szállodai szakmai szervezet (Magyar Szállodaszövetség) és az akkori felügyelő minisztérium az adatelóállítás és -publikáció gyorsítása érdekében (felhasználói igények) szorgalmazta, azonban az érintett szállodák ellenállása (szerintük indokolatlan adatszolgáltatói teher) és rendszeres normaszegése miatt 2010 után meg kellett szüntetni. Egyes eredményei három éven keresztül, hasonló címmel megjelentek a KSH gyorstájékoztatóiban, illetve turisztikai évkönyveiben.

A szálláshely-szolgáltatást a második világháborút követően jó pár évig az akkori szociálpolitikában fontos szerepet játszó ún. üdülési szálláshelyek jelentették, amelyeket csak meghatározott - döntően belföldi - vendégkör vehetett igénybe, és a létesítményeket a szakszervezetek és nagyobb állami vállalatok, szövetkezetek üzemeltették saját tagjaik és munkavállalóik számára. (Annak kifejtésére, hogy maguk a létesítmények hogyan is ,jöttek létre" (államosítás) terjedelmi korlátok miatt nincs mód, ám a - nagyságrendekkel kisebb - hálózat nem volt példa nélküli a háború előtt sem.) Kenessey Zoltán [1961] az 1950-es évek társadalomstatisztikai fejlödésének fontos állomásai között sorolja fel az üdülőkre és üdültetésre irányuló adatgyüjtések kidolgozását. Szerény terjedelemben, önálló füzetben 1951-ben és 1952-ben publikáltak már adatokat, de ezek a megjelenések esetlegesek voltak.

A létesítmények között voltak színvonalas gyógyüdülök, SZOT-üdülök (Szakszervezetek Országos Tanácsa). Az üdültetési tevékenységet az akkori szakirodalom mint „szociálturizmust” említette. A gyüjtött adatok köre a kereskedelmi szálláshelyekénél szükebb volt, a kapacitásra, a munkaügyre, a vendégforgalomra és a térítési díjakra szorítkozott. A szálláshelyek többsége az 1990-es évek elejei privatizáció után kereskedelmi szálláshely lett, kisebb részük - lényegében megtartva eredeti rendeltetését - szakszervezetek, vállalkozások tulajdonában nem üzleti céllal üzemeltetett, ún. nonprofit szálláshelyként müködött tovább.

Az 1961 és 1990 közötti időszakban az üdülési szálláshelyek évente egy alkalommal számoltak be tevékenységükről („Jelentés az üdültetési tevékenységről”, majd 1990 után „Jelentés a nem üzleti céllal üzemeltetett szabadidős szálláshelyekről” címmel) a KSH számára. Az adatok publikálása 1951-1952-ben elszórtan, majd 1955 óta rendszeresen a statisztikai évkönyvekben, 1963 és 1972 között „Szervezett üdülés" címmel önálló kiadványban, 2010 óta pedig éves jelentésként összefoglaló kiadványban (is) történt. Ezeket a szálláshelyeket egyes publikációk „nonprofit szálláshelyekként" említik, utalva a nem üzleti célú hasznosításra. A müködtetési feltételeket szabályozó kormányrendelet felső küszöbértéket, vendégforgalmi arányokat határoz meg az üzleti célú (kereskedelmi) hasznosításra.

Szálláshely-statisztika tekintetében az Európai Unió 692/2011. sz. rendelete ad eligazítást, és ennek a hazai gyakorlat majdnem teljes egészében megfelel (Az Európai Unió Hivatalos Lapja [2011]). A rendelet előzménye egy 16 éven át (1995-2011) 
érvényben levő irányelv volt. A jelenlegi jogszabály az Eurostatnak határidőkre átadandó mutatókat jelöli meg részletesen, azt azonban nem határozza meg, hogy az országok milyen módszerrel vagy technikával gyüjtsék az adatokat. A rendelet a szálláshely-statisztika mellett a nemzeti turizmus, a lakosság belföldi és külföldi turisztikai utazásainak statisztikai számbavételét is szabályozza.

A lakosság jövedelmi viszonyait, jóllétét többek között az is tükrözi, hogy milyen mértékben és arányban áll rendelkezésére üdülővagyon, és ezt hogyan hasznosítja. Az elöbbi kérdésre a hivatalos statisztika a népszámlálások során kísérelt meg válaszokat kapni, még akkor is, ha a nemzetközi tapasztalatokban szinte nem is található erre vonatkozó példa. Kifejezett üdülő-összeírás először az 1980. évi népszámláláskor volt, ebből azonban - a feldolgozott adatok megismerését követően - a nyilvánosság számára szánt publikáció nem készült. A kudarc oka az volt, hogy a bevallásra alapozott összeírás során a második lakások, üdülők tekintetében a lakosság inkább az eltitkolás mellett döntött, az adminisztratív nyilvántartások akkori állapota nem segített e helyzeten.

A népszámlálások történetében az üdülők teljes körű összeírása és az eredmények részletes feldolgozása utoljára a 2001. évi népszámláláshoz kapcsolódóan valósult meg. A 2001. évi népszámláláskor az üdülők összes száma - lakott és nem lakott együtt - 252295 volt. Ennek a népszámlálásnak a vonatkozó részletesebb adatai az egyes részpublikációkban fellelhetők.

A teljes körủ üdülö-összeírást a siker reményében csak a nyári üdülési időszakban lehetne elvégezni, amikor az üdülőkben elérhetők az adatszolgáltatók. Mivel a népszámlálásokat régóta az érintett évek fordulója táján hajtják végre (2011-ben októberben került rá sor), az üdülőszámlálás egy önálló összeírás szervezését és végrehajtását tenné szükségessé, és meglehetősen költséges feladat lenne. Ilyen megfontolások miatt 2011-ben teljes körü üdülö-összeírásra ugyan nem került sor, de a népszámlálás valamennyi címmel elszámolt, az üdülők száma ez alapján nagy biztonsággal becsülhető. Az üdülők összes száma pedig a népszámlálás utáni címállomány szerint 236254 volt. A változásban az építések, bontások mellett szerepet játszanak elsősorban agglomerációs területeken - a korábban üdülőnek épített, de később lakásként használt, a következő népszámlálás során már lakásként összeírt lakóegységek. Az üdülőépítmények számára vonatkozó, korábbiaknál pontosabb becslés csak a pontosabb és naprakészebb adminisztratív nyilvántartások felhasználásával lenne lehetséges. A belföldi utazásokról szóló felvétel (lásd az 1.3. alfejezetet) ugyan évek óta megkísérli a lakossági üdülőállomány felmérését, ez a próbálkozás azonban eddig nem vezetett eredményre.

Az üdülő- és második otthonvagyon hasznosításáról némi eligazítást ad a szálláshely-statisztika. 


\subsection{Belföldi turizmus}

A belföldi idegenforgalom jelentőségének felismerése már az 1970-es évek elején arra ösztönözte a szakembereket, hogy keressék a megoldásokat a lakosság turizmusának érdemi tanulmányozásához általánosan alkalmazható statisztikai módszerek kidolgozására. Hiszen érzékelhető volt, hogy a belföldi idegenforgalom elérte azt a szintet, amikor az iránta megnyilvánuló társadalmi igények nyomon követése egyre fontosabb. Ez pedig csak úgy valósítható meg, ha ennek az összetett és bonyolult társadalmi jelenségnek, gazdasági folyamatnak, illetve azok okainak, mozgatórugóinak, belső törvényszerüségeinek feltárása kellö alapossággal történik. Ehhez pedig megfelelő mennyiségủ és minőségü információra van szükség, amit csak jól müködő statisztikai információs rendszer biztosíthat. Az 1970-es években az európai országok jelentős részének a teljes belföldi idegenforgalom megfigyelésére még nem voltak kialakult és jól bevált módszerei.

Pálos István [1971] tanulmányában 7 millió före és 45 millió éjszakára becsülte - kirándulások nélkül - a magyarországi lakosság belföldi idegenforgalmát, amelyből a magánüdülés és víkendezés 3780 ezer fővel és 25200 ezer éjszakával részesült.

Probáld Ákos [1973] arra hívta fel a figyelmet, hogy az idegenforgalmi adatgyüjtési rendszer az ún. szálláshelyigényes belföldi turizmus kereskedelmi és üdülési szálláshelyeken megjelenő részén kívül, tulajdonképpen csak az utazási irodák közvetítésével bonyolódó forgalmat volt képes nyomon követni. Az idegenforgalmi szálláshelyek vendégforgalmi adatai pedig még csak hozzávetőlegesen sem jelezték a belföldi idegenforgalom volumenét. Ezen adatok alapján még következtetni sem lehetett arra, hogy vajon a teljes belföldi idegenforgalomban eltöltött idő milyen nagyságrendü lehet, nem is beszélve a turizmus kapcsán megjelenő vásárlóerő (költekezés) nagyságára. Az adatgyüjtési rendszer ugyanis nem biztosított adatokat a szálláshelyigényes belföldi turizmus egyéb megjelenési formáiról, arról a részről, ami saját nyaralókban vagy ezek tulajdonosainál térítés ellenében, üdülőterületek őslakosainál, sportegyesületek és egyéb szervezetek létesítményeiben jelent meg. Ugyancsak kívül rekedt a megfigyelési körön a teljes kirándulóforgalom. Már akkor feltételezhetö volt, hogy a belföldi turizmus magántulajdonú létesítményei felé irányuló része, valamint a kirándulóforgalom fog a jövőben a legdinamikusabban fejlödni.

Statisztikatörténeti érdekesség - még akkor is, ha eredményeit komoly fenntartásokkal lehet kezelni -, hogy 1970-ben a KSH a Magyar Államvasutakkal és az akkori Útügyi Kutató Intézettel együttműködve forgalom- és utasszámlálást végzett a Balaton körzetében. Ennek eredményeként sikerült legalább nagyságrendileg megbecsülni, hogy az ország kétségtelenül leglátogatottabb nyári üdülőkörzetét egy-egy idegenforgalmi idényben milyen vasutat igénybevevő turistatömeg keresheti fel. A kísérleti felvétel - amelynek azután nem volt folytatása - a legfontosabb balatoni 
állomásokon a leszálló utasokat számlálta, miután az adatgyüjtés megállításos kikérdezéssel nem párosult, a belföldi és a külföldi forgalmat nem különítette el. A felvétel eredményeit nem publikálták.

Hivatalos statisztikai felvételek hiányában történtek akkoriban kísérletek a magyarországi belföldi idegenforgalom jellemzőinek feltárására a piackutatás módszereivel. Az Országos Piackutató Intézet 1970 és 1972 között az Országos Idegenforgalmi Tanács megbízásából három alkalommal végzett kérdőíves megkérdezést a lakosság körében a szabadságidő eltöltéséről, illetve utazási szokásaikról. A publikációkból nem derült ki, hogy milyen mintavételi módszert alkalmaztak. A hozzáférhető adatok nem voltak elég részletesek, csupán nem, életkor, foglalkozás, iskolai végzettség, jövedelem, lakóhely és gépkocsitulajdon szerint vizsgálta a részvételt a belföldi turizmusban. Nem kapott választ az érdeklődő olyan nyilvánvalón fontos kérdésekre, mint például a különböző üdülőterületek hogyan részesedtek az eltöltött időből, hogy mely üdülőterületen milyen szálláshelyre volt igény, és kevés információ állt rendelkezésre a hétvégi utazásokra, kirándulásokra vonatkozóan is.

Az Országos Piackutató Intézet - a Marx Károly Közgazdaságtudományi Egyetem Belkereskedelmi Tanszéke mellett - a lakossági felvételeken túl a külföldi turisták körében, elsősorban költekezésük vizsgálatára végzett reprezentatívnak szándékolt felvételeket. Érdekesség, hogy a KSH 1970 és 1973 között éves idegenforgalmi kiadványainak függelékében szükségesnek ítélte ezen felvételek összefoglaló adatainak közzétételét.

A KSH 1972-ben kialakított egy egységes ún. általános célú mintát, illetve létrehozta az ELAR-t (Egységes Lakossági Adatgyüjtési Rendszer), melynek célja az volt, hogy olyan állandóan frissen tartott mintavételi keretet hozzon létre, amely a következő években megvalósuló lakossági adatgyűjtések alapját szolgálja. Az általános célú minta felépítését két-, illetve háromlépcsős rétegzett kiválasztással oldották meg: az első lépésben a települések, a másodikban ezeken belül a számlálókörzetek, a harmadikban a lakások (háztartások) kiválasztása történt. Ez utóbbi megfigyelési egységek az egész ország lakosságát voltak hivatva reprezentálni. Az általános célú minta adta két népszámlálás közötti időszakban az egyes speciális adatfelvételek keretét. A turizmus először 1979-ben került az ELAR programjába. Ez volt az első olyan országos vizsgálat, amely egy teljes évet fogott át. A felvételeket az ELAR 2 százalékos számlálókörzeti mintáján belül kialakított 2 ezrelékes lakásmintáján hajtották végre, melybe minden 15 éves és idősebb személy bekerült. A kérdezőbiztosok egy évben négyszer keresték fel a háztartásokat, és a megelőző három hónapban megvalósult egy- és többnapos utazások jellemzőit rögzítették. A felvétel során 7,6 ezer háztartás 17,4 ezer tagjának utazásáról gyüjtöttek információkat. Az önkéntes válaszolás mellett a válaszmegtagadás csekély volt, a lakosság rendelkezésre állása, a felvétel fogadtatása kifejezetten kedvező volt. Az adatok feldolgozása az akkori technológiai feltételek mellett lassan történt, az első összefoglaló értékelés 1982 
decemberében „A lakosság idegenforgalmának társadalmi, gazdasági jellemzői” címmel jelent meg ( $K S H$ [1982]). A 125 oldalas kiadványból 25 oldalnyi elemzés és 71 oldalnyi táblázatos rész volt, a fennmaradó oldalakon a használt fogalmak definíciója, az alkalmazott kérdőívek, a felvétel módszertani leírása és a vizsgálatba vont települések felsorolása szerepelt.

Az újabb vizsgálatra 1985-ben került sor. Mintája az 1980. évi népszámlálási számlálókörzetekből kialakított 15 százalékos arányos számlálókörzeti, majd az ebből vett 382 települést felölelő 1316 körzetet tartalmazó 12 ezer háztartást és 31400 személyt tartalmazó már nem arányos minta, amit a feldolgozások során utólagos rétegezéssel, súlyozással korrigáltak. A havonta feltett kérdések a megelőző hónap valamennyi, a havi kikérdezések által le nem fedett időszak alatt megtett tartós (4 éjszakás vagy annál hosszabb) utak jellemzőire (dátum, időtartam, úti cél, motiváció, szállástípus, közlekedési eszköz) és az utazás, valamint a felmerült kiadások összegére és összetételére vonatkoztak. A felvétel eredményei - az 1979-es vizsgálattal összevetve - összefoglaló kiadványban jelentek meg, amely elemző részt nem közölt, de tartalmazta a használt fogalmak definícióit, a felvétel módszertani leírását, az alkalmazott kérdőíveket, a vizsgálatba vont települések felsorolását és 147 oldalnyi táblázatokba foglalt adatsort ( $K S H$ [1987a]).

Az 1996. évi felvétel során, a mikrocenzus kísérő felvételeként, már 17 ezer háztartás kikérdezésére került sor. Ennek kérdezési programja szerényebb volt elődeinél, ugyanis - kísérő felvétel jellegéből adódóan - tekintettel kellett lenni az érintettek válaszadási tűrőképességére. Míg a mikorcenzusnál kötelező, addig az utazási szokásokat tudakoló blokknál önkéntes volt a válaszadás. További hátrányt jelentett, hogy a korábbi felvételekkel szemben csupán egy felkeresés történt, így a felejtési hatás (torzítás) lényegesen megnött, hiszen a kérdezetteknek egy év eseményeire kellett visszaemlékezni. A felvétel mikrocenzushoz kapcsolása számos elönnyel is járt, hiszen nem kellett külön felkeresni a háztartásokat (költségmegtakarítás), a demográfiai, iskolázottsági, foglalkoztatottsági, lakásviszonyokat rögzítő kérdéseket már nem kellett feltenni (időmegtakarítás), ezeket az információkat össze lehetett kötni a turisztikai változókkal. A felvétel eredményeként képet lehetett alkotni a népesség szabadidő-felhasználásának jellemzőiről, a turisztikai célú utazási aktivitásról, az utazások motivációiról, földrajzi céljairól, az igénybe vett szállások típusairól, a közlekedési eszközökröl. Határozottan kirajzolódtak a kibocsátó és fogadó régiók, csakúgy, mint bizonyos jövedelmi csoportok eltérő viselkedése. A felvétel módszertani hátterét, eredményeit „Mikrocenzus 1996. A lakosság utazási szokásai” címü kiadvány 1998-ban foglalta össze ( $K S H$ [1998]).

A lakosság utazási szokásainak következő vizsgálatát 2004-ben, az uniós csatlakozást követően végezte a $\mathrm{KSH}$, már azoknak a szabványoknak az alkalmazásával, amelyet az Európai Unió Bizottsága a 95/57. sz. irányelvében és 99/34. sz. határozatában rögzített, és amelynek a magyar statisztikai hivatal az elsők között megfelelt. A 
felvétel során az ausztriai „Reisegewohmheiten der Österreicher” (Osztrákok utazási szokásai) és a spanyol „Familytour” (A spanyolok utazási szokásai) című adatgyüjtés tapasztalatai hasznosnak bizonyultak.

A modernizált felvétel sikeressége, a válaszolási hajlandóság élénkítése érdekében az első két évben - a statisztikai szolgálat életében szokatlan és intenzív - kampányt indított a KSH. A felvétel indulása előtt rádiós és a televíziós spotok, a turizmusstatisztikát népszerüsítő kisfilmek készültek, ${ }^{3}$ és a kiemelt műsorok adásidejében és sávjában kerültek adásba. A vizsgálatba sikerrel bevont háztartások szerény szóróajándékokat kaptak, ső́t számukra negyedéves utazási magazin készült („Számokban utazunk" címmel ${ }^{4}$ ) rejtvényekkel, a megfejtőknek értékes ajándékokkal, amelyeket a turisztikai szolgáltatók (szállodák, éttermek, utazási irodák és mások) ajánlottak fel.

Bár a kampány eredményes volt, de a KSH költségvetési indokokkal megszüntette, aminek érezhető negatív hatása volt a további felvételek megvalósulására.

Az adatgyüjtés megfigyelési egysége volt a mintába került lakásban élő háztartás, illetve a háztartás minden egyes tagja, korhatártól függetlenül. Ebben eltért az európai szabványtól, amely csak a 14 éven felüliekröl szól, de ez az eltérés nem sértette az előírásokat, mert az adatátadásnál az eredményeket csak a 14 éven felüliekre vonatkoztatták. A felvétel mintavételi terve a KSH elveit, hagyományait követte és követi napjainkban is, ma már a 2011. évi népszámlálásra alapozva. A minta 613 településből és 233 rétegből állt, 15 ezer háztartást érintett. Az átfogó - az elmúlt tizenkét hónap utazási élményeire vonatkozó - kikérdezésre évente négyszer került sor, április, július, október és január hónapokban. Összeírták a háztartás összetételére vonatkozó információkat, minden tagjának demográfiai, iskolázottsági, gazdasági aktivitási stb. jellemzőire vonatkozó adatokat és a háztartás nyaralóingatlanát érintő információkat is. Rögzítették a háztartás tagjainak minden ún. tartós utazását (legalább egy éjszakázás), az utazás hónapját és időtartamát, az utazás földrajzi célját, a motivációt, az igénybe vett szállás típusát, a használt közlekedési eszközt, az utazás szervezettségét és nem utolsó sorban az utazáshoz kapcsolódó kiadásokat, valamint azok szolgáltatások (szálláshely, vendéglátás, közlekedés, egészség-megörzési, kulturális stb.) és áruk (élelmiszerek, üzemanyag, emléktárgyak stb.) szerinti részletezettségét.

A felvételt azóta minden évben végrehajtja a hivatal, igazodva a turisztikai statisztika követelményeit újra fogalmazó - az 1995-os irányelvböl 2011-ben rendeletté (Az Európai Parlament és a Tanács 692./2011./ EU Rendelete a turizmusra vonatkozó európai statisztikákról) továbbfejlesztő - szabványhoz, hogy negyedévente nyers (mikro-) és feldolgozott adatokat adjon át az Eurostatnak, amely minőségellenörzés

\footnotetext{
${ }^{3}$ A népszámlálások és a mikrocenzusok környezetében a KSH ma már alkalmazza ezt a promóciós technikát.

4 A „Számokban utazunk” cím és logó - mintegy védjegy - a mai napig szerepel a KSH Tájékoztatási Adatbázisának „Turizmus vendéglátás” címü menüpontjának fejlécében.
} 
után beilleszti a többi 27 uniós tagország adatait tartalmazó adatbázisba, és publikálja is azokat.

A felvétel legfontosabb jellemzői (méret, gyakoriság, vizsgálatba vont változók) 2004 óta csak akkor változtak, ha az európai szabvány módosult, illetve amikor a 2011. évi népszámlálás mint mintavételi háttér már rendelkezésre állt (2015. évi felvétel). Néhány, az idők során az utazás, a turizmus szempontjából fontossá vált elemet - például a bank kártyával, SZÉP-kártyával (Széchenyi Pihenőkártya) megvalósított fizetést, az internethasználatot - is be kellett illeszteni a kérdezési programba. A felvétel(ek) kérdőívei néhány éve már hozzáférhetők a KSH honlapján. Változott és fejlődött a felvétel technikai, technológiai eszközrendszere (például a papíralapú kérdőívről 2015-ben a tablet használatra tértek át), informatikai támogatottsága és kérdezőbiztosi hálózatának szervezettsége.

A lakosság utazási szokásainak felvételeiről önálló publikáció a KSH „Statisztikai Tükör" sorozatában készült 2007 és 2008 között félévenként, 2009-ben negyedévenként, 2010 és 2011 között újra félévenként, 2012 óta minden évben az első három negyedévröl (a turisztikai föidényt követően) összevontan. Az éves értékelések közreadására elektronikus kiadványban kerül sor.

Tekintettel a népesség összetételében 2001 és 2011 között bekövetkezett strukturális változásokra 2015 márciusában, a 2008 és 2014 közötti évek tekintetében újrasúlyozással adatrevízióra került sor, a 2011. évi népszámlálás adatai alapján.

A lakosság turisztikai fogyasztására vonatkozó adatait a nemzeti számlák felhasználási oldalán, ha közvetlenül nem is használják fel, de ellenőrzési és validálási szándékkal figyelembe veszik.

A lakosság turisztikai célú kiadásait, fogyasztását a háztartási költségvetési felvételek, időfelhasználását a tízévenként ismétlődő időmérleg-vizsgálatok rendszeresen felmérik, ezek azonban inkább a korábban felsorolt felvételekhez nyújtanak adalékokat, de a velük való összehasonlításra csak korlátozott mértékben alkalmasak.

A lakosság külföldi utazásait külön adatgyüjtésekkel vizsgálta, illetve vizsgálja ma is a KSH.

Kezdetben a demográfiai statisztika keretében, 1950 és 1958 között annak „külső vándorlás" fejezetében, a Határőrség bevonásával figyelték meg a határt átlépő magyar állampolgárok számát, teljes körü, kérdöíves felvétel alkalmazásával. Az adatokat rendszeresen a Demográfiai Évkönyv, valamint a Magyar Statisztikai Évkönyv „Külső vándorlás” fejezete közölte. A Statisztikai Havi Közleményeknek már 1959tól volt „Idegenforgalom” címü önálló fejezete, és itt láttak napvilágot fokozatosan bővülő, az utazási motivációt, a külföldön eltöltött időt és a célországokat részletező az adatok. 


\subsection{Utazásszervezés és -közvetítés}

Bár a csoportos utazás Európában már a XIX. században megjelent (Thomas Cook és irodájának neve közismert), Magyarországon pedig 1902-töl, az IBUSZ létrehozása óta volt ismert, az utazásszervezés, az utazási irodák tevékenysége csak az 1960-as évek közepén került igazán a statisztika látóterébe, bár Kovács László és Takács János [1966] nem említ ilyen jellegü adatgyüjtést. Az Idegenforgalmi Adattár (KSH [1966]) 1958-tól közöl utazási irodák forgalmára vonatkozó adatokat, furcsa ezért, hogy az adattár szerkesztője Takács János [1971] „A kereslet statisztikai mérésének módszerei" című tanulmányában sem tartja fontosnak megemlíteni a szervezett idegenforgalomra vonatkozó adatgyüjtést. Ekkor pedig a már több, mint 60 éves IBUSZ mellett először az Express Diák és Ifjúsági Utazási Iroda kezdte meg a müködését, majd sorra alakultak más irodák is (Cooptourist, Volántouris, Budapest Tourist, MALÉV Air Tours), sőt a megyei idegenforgalmi hivatalok is a szervezett idegenforgalom felé kezdtek fordulni, és mindezen egységek tevékenysége átlépte az érzékenységi küszöböt, teljesítményük megkívánta a statisztikai követést. Az erre szolgáló „A szervezett idegenforgalom teljesítményei” címü adatgyüjtés 2003-ig negyedéves, mellette 1993 és 2003 között „Jelentés az utazásszervezők árbevételi és foglalkoztatottsági adatairól" címmel éves gyakoriságú, 2003-tól kezdve az előzők összevonásával „Jelentés az utazásszervező és közvetítő tevékenységről” címmel csak éves gyakoriságú volt. A szervezett idegenforgalom adatkörei a beutaztatás, kiutaztatás (mindkettő küldö-, illetve célországok bontásban) vendégforgalmi, az elözőkhöz kapcsolódó bevételi, valamint a hálózati és létszámadatokat ölelték fel. Az évek során az ,ágazat” egyre erősödött, napjainkban már több, mint ezer utazásszervező vállalkozás rendelkezik tevékenységi engedéllyel. A „Főbb idegenforgalmi adatok" címü kiadvány 1966-ban már két oldalon tartalmazott utazási irodákra vonatkozó vendégforgalmi adatokat. Ezt követően az évközi és éves idegenforgalmi adatgyüjteményekben rendszeresen szerepeltek az utazási irodák teljesítményei.

\section{Turizmus a nemzetközi fizetési mérlegben és a szatellitszámlákban}

Az MNB fizetési mérlege már az 1930-as években tartalmazott „kvázi” idegenforgalmi adatokat, ezeket lényegében becsülték, figyelembe véve az „útiköltségeket” is. Ebböl kiderül, hogy „...1937-ben az idegenforgalom által képviselt „láthatatlan export" kimutatott gazdasági haszna valutaszerző eröben a vágómarha és a búza 
kivitel után a harmadik helyen áll...” olvasható a „Jelentés Budapest Székesfőváros Idegenforgalmi Hivatalának 25 esztendős munkásságáról 1916-1941” című dokumentumban (Markos [1943]).

Kolacsek és Markos [1958] így fogalmaznak: „...az idegenforgalom gazdasági eredményei szétáradnak az egész népgazdaság területén, $s$ minthogy egyéb más természetü tételekkel fonódnak össze, pontos összegük a fizetési mérleg keretében nem mutatkoznak meg...”. Leszögezik, hogy „,...a nemzeti bankok kimutatásaikban a közlekedési költségek ... nem szerepelnek. ...Nem tartalmazzák továbbá azokat az összegeket, amelyeket a külföldiek ... a megfelelö devizaszabályok értelmében bevihetnek és ott elkölthetnek. Amennyiben nincsen mód és lehetőség az összes adat beszerzésére akkor a nemzeti bankok nyújtotta részadatok figyelembe vételével becslésekkel kell megállapítani az idegenforgalmi bevételeket."

Hajdú Györgyné [1970] tanulmányában az idegenforgalom külgazdasági jelentőségét hangsúlyozva arról elmélkedik, hogy az idegenforgalom milyen súlyt képvisel az áru- és szolgáltatás-külkereskedelem egészében, a külgazdasági egyensúly tekintetében. Legalább ilyen fontos annak jó becslése, hogy milyen a turizmus szerepe a külső államadósság enyhítése szempontjából. A nemzetközi fizetési mérleg módszertanának részletezését mellőzzük, de érdekes megjegyezni, hogy az MNB már a cikk születésekor követte a Nemzetközi Valutaalap módszertanát, és a fizetési mérlegében külön sorokat (bevétel - export és kiadás - import oldalon) szentelt az idegenforgalomnak. A választható módszerek közül akkor - az ún. kötött devizagazdálkodás szabályai mellett - azt a tételes megfigyelésen alapuló eljárást választotta, melyben biztosítható volt, hogy megfelelően elkülöníthető legyen a külföldiek valutabeváltása, a külföldre utazók valutaellátása, a közvetlenül az utasok kezén át nem menő, csupán a bankok, pénzintézetek közötti, a szálláshely-szolgáltatók, az utazási irodák révén megvalósult tranzakciói is. A fizetésimérleg-adatokat a KSH függetlenül attól, hogy maga adatot nem gyüjtött, az idegenforgalommal összefüggő MNB-adatokat saját kiadványaiban közölte.

A forint konvertibilissé válásával ez az eljárás többé nem volt követhetö. Maradt az a „közvetlennek” nevezett módszer, amelyet a Nemzetközi Valutaalap már az 1960-as évek elején ajánlott, és amelyet a mai napig követ az MNB. Az MNB azonban közvetlen adatgyüjtést nem végez - bár igen összetett és kiterjedt, az európai statisztikák rendszeréhez, az Európai Központi Bank előírásaihoz igazodó adatgyüjtési rendszere van - csupán az áru- és szolgáltatás-külkereskedelemmel összefüggőadatokat vesz át a KSH-tól. Ezek között szerepelnek az utasforgalomra vonatkozó adatok, benne a külföldiek magyarországi költekezésére, a magyar állampolgárok külföldi fogyasztását becslö, jelent tanulmány határstatisztikáról szóló fejezetben részletezett adatok is. A KSH saját kiadványaiban külföldi, illetve külföldön megvalósult lakossági fogyasztásnak - a lakossági belföldi turisztikai fogyasztásával együtt már nemzeti turisztikai fogyasztásnak - tekinti a rezidens személyszállítóktól vásá- 
rolt szolgáltatásokat is, amelyet az MNB - a Nemzetközi Valutaalap módszertanhoz történő igazodás miatt - a közlekedési szolgáltatások között számol el. A KSH ezen túl publikációiban az utasforgalmat és a hozzá tartozó fogyasztást is megbontja a turisztikai, illetve más motivációval utazók szerint.

Az MNB felelősségi körébe tartozó nemzetközi fizetési mérleg tekintetében a szolgáltatás-külkereskedelem és a turizmus (persze a turizmus nyugodtan érthető e tágabb fogalom körébe) elszámolása sok-sok tennivalót rejt még. ${ }^{5}$

Hazai szakmai körökben kevéssé ismert, hogy a turizmusnak a gazdaságban megvalósuló és tovagyürüző hatásának bemutatására a turizmus-szatellitszámlák gondolata már az 1950-1960-as évek fordulóján felmerült, bár akkor még nem ezzel a megnevezéssel. Az Idegenforgalmi Közlemények 1970/1-2. száma „Új megvilágításban a multiplikátorhatás a turisták pénzköltésének elemzésében" címmel, Lengyel Márton fordításában közli egy francia közgazdász, Sommerset R. Waters írását. (Waters [1970]).

A KSH gyakorlatában nem a turizmus az egyetlen terület ahol alkalmazzák a szatellitszámlát (Nyitrai [1999]). Nem sokkal később a háztartások nemzetgazdasági elszámolásokban játszott szerepének sajátos megközelítését 2003-ban egy KSH mühelytanulmány mutatta be (KSH [2003].

„A turizmus szatellit számla egy statisztikai rendszer, amelyben a szatellit kifejezés arra utal, hogy a turizmussal kapcsolatos statisztikai mutatók (a turizmus részesedése a bruttó hazai termékben, a turizmusból származó költségvetési bevétel, a turizmus foglalkoztatás növelő hatása stb.) beilleszkednek a makrogazdasági statisztikák, a nemzeti számlák rendszerébe. Ez biztosítja a turizmusra vonatkozó statisztikák belső összhangját, valamint azt, hogy olyan mutatókat tudjunk kiszámítani, amelyekkel a turizmus rövid és hosszú távú jövedelmezősége egyértelműen és tömören összevethető más ágazatok hasonló mutatóival. A szatellit jelző azt a kapcsolatot szimbolizálja, hogy a turizmusra összpontosító részletes statisztikák úgy igazodnak a nemzeti számlákhoz, mint a naprendszerben a bolygók a naphoz." (Hüttl-Probáld [2000])

Vagyis a turizmus-szatellitszámlák rendszere a nemzeti számlák módszertanát, meghatározásait és osztályozásait alkalmazza, melyek használatával kimutatható a turizmusra jellemző ágazatok kibocsátásának és hozzáadott értékének aránya a teljes nemzetgazdaságon belül. A turizmus-szatellitszámlák segítségével mérhető a turizmus átfogó gazdasági teljesítménye. Keresleti oldalon a külföldi és lakossági utazások és költések, kínálati oldalon a turizmus - nemzeti számlák módszertanával elő́llított - termelési számlái jelennek meg, így mutatható ki, hogy mennyi a turizmus hozzájárulása a gazdasághoz és mennyi a turizmusban a foglalkoztatottak aránya.

\footnotetext{
${ }^{5}$ Többek között a fizetési mérleg ún. ,jogcímezése”, a fekete- és szürkegazdaság - lehet, hogy csökkenő, de kétségkívül - virulens jelenléte miatt sem a turizmusnak tulajdonított bevételek, sem a kiadások tekintetében nem lehetünk bizonyosak abban, hogy milyen nagyságrendủ tételek hiányoznak a fizetési mérleg „idegenforgalom" fejezetéből, illetve esetleg milyen oda nem illö tételek terhelhetik azt.
} 
A turizmus szatellitszámláival foglalkozó munkálatok a KSH-ban már 1999-ben elkezdődtek, de igazi lendületet akkor kaptak, amikor a hivatal sikeresen pályázott az EU Vállalkozáspolitikai és ipari főosztályának felhívására, anyagi támogatására. Ennek az volt az eredménye, hogy elöször 2004-ről sikerült összeállítani a számlákat, amit 2006-ban publikáltak.

Ezt követően kisebb szünet után - most már elektronikus formában - egészen 2015-ig jelentek meg azok a kiadványok, amelyek ezekkel a számlákkal foglalkoztak. A munka jelenleg is folytatódik, és a felhasználó - első sorban kormányzati, gazdaságpolitikai - döntéshozók igényeinek ismeretében minden bizonnyal folytatódni is fog. Az alkalmazott módszer megfelel a nemzetközi szervezetek - az ENSZ Turisztikai Világszervezete, az ENSZ Statisztikai Divíziója, az OECD (Organisation for Economic Co-operation and Development - Gazdasági Együttmüködési és Fejlesztési Szervezet) és az Eurostat ajánlásainak. A turizmussal foglalkozó - korábban említett - EU-rendelet azonban nem ír elö ilyen kötelezettséget. Az 5. cikk 2. bekezdésében foglalkozik a számlákkal, melynek kapcsán már kísérleti projektek is születtek azzal a céllal, hogy az európai országokban megvalósulhasson egy egységes elveken nyugvó rendszer. Az Eurostat legutóbb 2017 elején közzé is tett egy ezzel a kérdéssel foglalkozó kiadványt (Eurostat [2017]).

\section{Tájékoztatás és szervezeti keretek}

A turizmusra (idegenforgalomra) vonatkozó adatok publikálása hosszú ideig, gyakorlatilag a hatvanas évek közepéig csak valamilyen általános, összefoglaló adatgyüjtemény keretében valósult meg.

Elöször 1966-tól kezdve jelent meg egy évben hat alkalommal, az idegenforgalmi idényhez kapcsolódóan önállóan, eleinte stenciles formában, majd nyomdai úton sokszorosítottan a „Főbb idegenforgalmi adatok” (1966-1970) című (majd különböző címváltozatokkal „Idegenforgalmi statisztikai adatok”, „Idegenforgalmi statisztika”, „Az idegenforgalom alakulása”) évközi, határforgalmi és szálláshely-statisztikai adatokat, illetve az utazásszervező vállalkozások (utazási irodák) adatait tartalmazó kiadvány.

Az első, hosszabb idősorokat, részletes adatokat közlö publikáció az 1958 és 1965 közötti éveket összefoglaló Idegenforgalmi Adattár (KSH [1966]) volt.

Ezt követően már rendszeresen jelentek meg az éves adatokat közlő publikációk: Az idegenforgalom alakulása (1967-1970), Idegenforgalmi statisztika (1971-1979), Idegenforgalmi Évkönyv (1981-1997), Idegenforgalmi statisztikai évkönyv (19992004), Turisztikai Évkönyv (2005). Az évkönyv jellegű adatgyüjtemények 2006-tól 
megszüntek, helyüket a szöveges elemzést és viszonylag részletes, de az évkönyvekénél lényegesen rövidebb adatközlést tartalmazó összefoglalók készültek: Turizmus (2003-2004), Jelentés a turizmus teljesítményeiröl (2005-2013-ig), Turizmus és vendéglátás (2014), Jelentés a turizmus és vendéglátás teljesítményeiről (20152016).

Miután a digitális forradalom a statisztikát is elérte, a turisztikai statisztika információinak közzétételi formája, technikája is idomult ezekhez az adottságokhoz. Eltűntek a turizmusról szóló nyomtatott publikációk, a felhasználó igényeit a 2000-es években már a KSH honlapjáról (www.ksh.hu), annak „Turizmus, vendéglátás” menüpontjáról elérhető elektronikus „Gyorstájékoztatók”, a statikus adatbázis a „STADAT” és a dinamikus, „Tájékoztatási Adatbázis” elégíti ki, számos a „Kiadványtárban” megjelenő szöveges és/vagy adat-összeállítást tartalmazó e-kiadvány mellett. A menüpont mai is az üzenetértékü „Számokban utazunk” fejlécet viseli, ez a szlogen még 2004-ben született a turizmusstatisztika összes, külvilág számára fontos ismeretének összefoglalására.

A turisztikai statisztika önálló szervezeti egység keretében 1964-ben jelent meg a KSH-ban, az akkori „Forgalomstatisztikai főosztályon” belül egyelöre még nem osztály rangján, hanem „Idegenforgalmi önálló csoport” néven, amelynek létszáma hat fö volt. A csoport ekkor döntően a kereskedelmi szálláshelyekről és az utazási irodáktól gyüjtött adatokat, az előbbieket területi szervezetei, a megyei igazgatóságok közremüködésével, utóbbiakat közvetlenül. A határstatisztika ekkor még a Népesedési föosztályhoz, a szervezett üdültetés statisztikája a Társadalmi szolgáltatások főosztályához tartozott, az Idegenforgalmi önálló csoport pedig ezektől vett át és publikált adatokat. Az idegenforgalmi devizabevételekre és -kiadásokra vonatkozó nemzetközi fizetésimérleg-adatokat az MNB-től vették át. A határstatisztika az 1970-es évek elején, a szervezett üdültetésre vonatkozó adatgyüjtés az évtized közepén került át a föosztály kompetenciájába. A nemzetközi turizmussal összefüggő bevételek és kiadások közvetlen adatgyüjtése 2004 után - a nemzetközi keresletstatisztika keretében - az MNB-től a KSH-hoz került, vagyis az adatátadás iránya megváltozott.

Az Idegenforgalmi önálló csoport 1970-ben egyre bővülő feladatai miatt Idegenforgalmi osztály néven müködött tovább, még mindig a Forgalomstatisztikai föosztály keretén belül, amely később Kereskedelmi és közlekedési statisztikai főosztályra, 1991-től Gazdasági ágazatok statisztikai főosztályra, majd Szolgáltatásstatisztikai főosztályra, 2013-tól Külkereskedelmi és szolgáltatásstatisztikai főosztályra, végül ismét Szolgáltatásstatisztikai föosztályra változott. ${ }^{6}$ A turizmusstatisztikát ezen időszakok alatt hol önálló osztályon (1987-ig Idegenforgalmi osztály), hol a közlekedés-

${ }^{6}$ A főosztályt 1987-ig Pálos István, majd Végvári Jenö (1987-1990), Pukli Péter (1990-1996), Probáld Ákos (1996-2013), Szabó Péter (2013-2015), Gilyán Csaba (2015-2017) vezette, jelenleg Valkó Gábor (2017) a főosztályvezető.

Statisztikai Szemle, 96. évfolụam 6. szóm 610-640. oldal 
vagy a belkereskedelmi statisztikával összevontan müvelték. Az osztály neve elöször Közlekedés, posta és idegenforgalmi osztály (1988), később Közlekedés és turizmus statisztikai osztály (1995), majd Belkereskedelmi és turisztikai osztály (2014) lett. Az osztály 2017 öszétől kezdve az Ágazati statisztikai főosztályon belül Turisztikai és szállításstatisztikai osztály néven müködik. ${ }^{7}$ A turizmussal foglalkozó munkatársak száma - részben a bővülő tematika, részben a fejlődő informatikai háttér következtében - hullámzó, az 1980-as évekig 6-8 fő volt, az összevonások után ennél is kevesebb, ma 4 fö.

\section{Nemzetközi kapcsolatok}

A nemzetközi kapcsolatokról 1990 előtt csak sporadikusan lehet beszélni. A nemzetközi szervezetek közül egyedül az UNWTO (United Nations World Tourism Organization - Egyesült Nemzetek Turisztikai Világszervezete) ${ }^{8}$ munkájába kapcsolódott be a $\mathrm{KSH}$, részben rendszeres adatszolgáltatóként, részben pedig esetenként egyes fórumain a statisztikai kérdések megvitatásában. A KGSTországok (Kölcsönös Gazdasági Segítség Tanácsa) részvételével 1970 és 1990 között müködött ugyan egy Idegenforgalmi Közgazdasági Bizottság, ${ }^{9}$ amely idöközönként aktuális kérdéseket vitatott meg, azonban alig fordult elö, hogy érdemi és az egyes országokban döntésekben megvalósult javaslatokat fogalmazott volna meg, saját döntési, szabályalkotási jogköre pedig nem volt. A bizottság ülésein statisztikai jellegü napirendek alig-alig szerepeltek, bár néhány, az idegenforgalmat jellemző egyszerübb adatcserére sor került; üléseire Varsóban, Szófiában és Prágában került sor. Magyarországnak a KGST-országok közül az Német Demokratikus Köztársasággal, Lengyelországgal és Csehszlovákiával alakultak ki a statisztikát érintő, szerény kétoldalú kapcsolatai.

A KSH 1990 után nagyobb súlyt fektetett a nemzetközi kapcsolatokra, ami - még az uniós csatlakozást megelőzően - az Eurostattal és az OECD Fejlesztési szervezet statisztikai részlegével, valamint az UNWTO-val való - többnyire az rendszeres, a kéréseket közel teljeskörüen kielégítő adatszolgáltatást végrehajtó - érintkezést jelentette.

\footnotetext{
${ }^{7}$ A turizmussal foglalkozó osztályt Takács Jánost követően 1987-ben Probáld Ákos vette át, 1996-tól Pelsőcziné Hosszú Katalin, utána Hegedüs Józsefné (1999), megbízott osztályvezetőként Rácz Albert (20002001), Gether István (2002-2007) majd Gilyán Csaba (2007-2017) vezette, és 2017 óta Kovács Csaba vezeti.

${ }^{8}$ Az 1975-ben életre hívott UNWTO vezető nemzetközi szervezetként előmozdítja a turizmust a gazdasági növekedés, az inkluzív fejlődés és a környezeti fenntarthatóság ösztönzőjeként, és vezető szerepet tölt be az ágazat számára a tudás, valamint az idegenforgalmi politikák világszintü előmozdításában.

${ }^{9}$ A Bizottság üléseinek rendszeres résztvevője volt a cikk szerzője is.
} 
Az Eurostat szakmai fórumain a csatlakozást megelőzően, az 1990-es évek közepétől megfigyelői státusban vett részt Magyarország. Ennek egyik látványos elismerése volt, hogy 2002-ben az Eurostat és az OECD Budapesten tartotta hatodik - egyébként kétévenként szervezett - Turisztikai Statisztikai Nemzetközi Fórumát, KSH és a Miniszterelnöki Hivatal Turisztikai Államtitkárságának szervezésében, rendezésében és finanszírozásában. A háromnapos fórum kiemelt témái a következők voltak:

- a turizmus gazdasági szerepe és fontossága az egyes nemzetgazdaságokban,

- a turizmus szerepe a foglalkoztatásban,

- a turisztikai kereslet és kínálat statisztikai megfigyelése,

- a turisztikai statisztika módszertani kérdései,

- a turizmus regionális problémái,

- a szabadidő és a turizmus összefüggései,

- a konferenciaturizmus jellegzetességei,

- az egészség- és gyógyturizmus jelentősége,

- a turizmus-szatellitszámlák.

A nemzetközi kapcsolatokban kiemelt jelentösége van annak, hogy Magyarország tevőlegesen részt vett a 2011-ben érvénybe lépett - korábban többször hivatkozott 692/2011/EU-rendelet kidolgozásában, amely azt szabályozza, hogy a tagállamoknak milyen statisztikákat kell a turisztikai keresletre és kínálatra vonatkozóan az Eurostat részére továbbítani. A tagállamok által elóállított statisztikákra vonatkozó ajánlásokat, a kért fogalom meghatározásokat és az adatminőség biztosítását célzó normákat, az Európai Unió Bizottsága által összeállított módszertani kézikönyv tartalmazza (Eurostat [2011]), melynek aktualizálásáért a bizottság felel, és eddig három alkalommal, legutóbb 2014-ben meg is történt. Magyarország a rendelet valamennyi adatátadásra vonatkozó elöírását betartja.

A tanulmány a turizmusstatisztika történetét csak felvázolni tudta, a gazdasági és társadalmi összefüggések statisztikai megközelítése számtalan kutatási témát tartogat. Bemutatásra vár még például a lakosság turisztikai fogyasztása a háztartásstatisztika adatbázisán, a lakosság üdülővagyonának gyarapodása a népszámlálások részletes feldolgozása alapján, vagy éppen a turizmus gazdasági beágyazottságának, súlyának bemutatása a turizmus szatellitszámláinak részletesebb feltárása révén. 


\section{Irodalom}

Az Európai Unió Hivatalos Lapja [2011]: Az Európai Parlament és a Tanács 692/2011/EU rendelete (2011. július 6.) a turizmusra vonatkozó európai statisztikákról és a 95/57/EK tanácsi irányelv hatályon kívül helyezéséröl. L 192. 2011. 7. 22. https://eur-lex.europa.eu/legalcontent/HU/TXT/?uri=celex:32011R0692

BELKERESKEDELMI KUTATÓ INTÉZET [1970]: A külföldi turisták költekezésének struktúrája. Budapest.

BESENYEI L. - PROBÁLD Á. [1975]: A nemzetközi idegenforgalom határstatisztikai megfigyelése. Statisztikai Szemle. 53. évf. 8-9. sz. 858-872. old.

BudAPEST SzÉKESFövÁRos IDEgENFORgalmi Hivatala [1928]: Jelentés Budapest 1927. évi idegenforgalmáról. Budapest.

BudAPEST SZÉKeSFÖVÁROS IDEGENFORGalmi Hivatala [1935]: Jelentés Budapest 1934. évi idegenforgalmáról és az 1934. évi idegenforgalom gazdasági eredményeiről. Budapest.

EuROSTAT [2011]: Methodological Manual for Tourism Statistics. Luxembourg.

Eurostat [2017]: Tourism Satellite Account in Europe - 2016 edition. Luxembourg. http://ec.europa.eu/eurostat/documents/7870049/7880233/KS-FT-17-002-EN-N.pdf/1070ebdcb9e1-4a93-abb8-cecd83d40f68

FENYÖ I.-NÉ [1966]: Az idegenforgalmi statisztika számbavételi módszere. Demográfia. 9. évf. 2. sz. 204-214. old.

HAJDU GY.-NÉ [1971]: A nemzetközi idegenforgalom devizális eredményeinek megfigyelése, illetve mérése. Idegenforgalmi Közlemények. 3. sz. Országos Idegenforgalmi Hivatal. Budapest.

Hüttl A. - ProBÁLd Á. [2000]: Turizmus és nemzetgazdaság. (Miért van szükség turizmus szatellit számlára?) Gazdaság és Statisztika. 12. (51.) évf. 1. sz. 39-49. old.

KENESSEI Z. [1961]: A Központi Statisztikai Hivatal adatgyüjtései és kiadványai. Statisztikai Szemle. 39. évf. 12. sz. 1238-1262. old.

KolaCseK A. - MARKos B. [1958]: Az idegenforgalmi statisztika időszerü problémái. Statisztikai Szemle. 36. évf. 7. sz. 655-665. old.

KolacseK A. - Markos B. [1959]: Az idegenforgalmi statisztika fejlődése. Statisztikai Szemle. 37. évf. 7. sz. 738-742. old.

KolACSEK A. [1970]: Az idegenforgalom helye Magyarországon. Idegenforgalmi Közlemények. 1-2. sz. Központi Statisztikai Hivatal. Budapest.

KovÁcs L. - TAKÁCs J. [1966]: Az idegenforgalom alakulása és fejlödése 1945-1965. Panoráma Kiadó. Budapest.

KSH (KöZPOnti Statisztikai Hivatal) [1958a]: Budapest statisztikai zsebkönyve, 1957. Budapest.

KSH [1958b]: Magyarország népesedése, 1957. Budapest.

KSH [1958c]: Magyarország szállodái és üdülői 1957. évben. Budapest.

KSH [1958d]: Magyar Statisztikai Évkönyv, 1957. Budapest.

KSH [1959]: Külföldi idegenforgalom és szállodahelyzet. Budapest.

KSH [1960]: Demográfiai Évkönyv, 1960. Budapest.

KSH [1965]: Magyarország szállodái 1963. június 30.-án. Budapest.

KSH [1966]: Idegenforgalmi Adattár, 1958-1965. Budapest.

KSH [1970]: Magyarország idegenforgalmi szálláshelyei, 1969. Budapest. 
KSH [1971]: Szervezett üdülés, 1970. Budapest.

KSH [1979]: Idegenforgalmi statisztika. Statisztikai fogalmak sorozat. Budapest.

KSH [1980]: Magyarország idegenforgalmi szálláshelyei 1978. július 31 -én. Budapest.

KSH [1982]: A lakosság idegenforgalmának társadalmi gazdasági jellemzői. Budapest.

KSH [1983]: A nemzetközi idegenforgalom határstatisztikai megfigyelésének módszertana. Budapest.

KSH [1987a]: A lakosság üdülési-utazási szokásai és kiadásai. Budapest.

KSH [1987b]: A nemzetközi idegenforgalom 1986-ban. Budapest.

KSH [1989]: Magyarország idegenforgalmi szálláshelyei 1987. július 31 -én. Budapest.

KSH [1998]: Mikrocenzus 1996, A lakosság utazási szokásai. Budapest.

KSH [2003]: A háztartási termelés értéke a mai Magyarországon - A háztartási szatellit számla 2000. évi kisérleti számításai. Műhelytanulmányok. Budapest.

KSH [2004a]: Magyarország turizmus szatellit számlái, 2004. Budapest.

KSH [2004b]: Nemzetközi idegenforgalom és a turisztikai kereslet jellemzöi, 2004. Budapest.

KSH [2005]: A lakosság utazási szokásai felvétel módszertana. Statisztikai módszertani füzetek. Budapest.

KSH [2006]: Jelentés a turizmus 2005. évi teljesitményeiröl. Budapest.

KSH [2016]: A háztartási munka értéke, háztartási szatellit számla Magyarországom. Budapest.

KSH [2017]: Turizmus-szatellitszámlák, 2014-2015. Budapest.

LENGyel M. [2004]: A turizmus általános elmélete. Heller Farkas Gazdasági és Turisztikai Szolgáltatások Főiskolája. Budapest.

Magyar GazdasÁgKutAtó InTÉZet [1938]: A magyar idegenforgalom alakulása 1927-1937. 13. sz. különkiadvány. Budapest.

Magyar KiRÁlyi StatiszTiKai Hivatal [1938]: Magyarország üdülö-, fürdö- és szállóhelyei, 1937. évben. Budapest.

Markos B. - KolaCSEK A. [1961]: Idegenforgalom. Panoráma Kiadó. Budapest.

MARKos B. [1927]: Az idegenforgalommal kapcsolatos gazdasági jelenségek s azok szerepe a gazdaságpolitikában. Városi Szemle. XXIX. évf. 1. sz. 80-103. old.

MARKos B. [1943]: Jelentés Budapest 1942. évi idegenforgalmáról. Budapest Székesföváros Idegenforgalmi Hivatala. Budapest.

Markos B. [1943]: Jelentés Budapest Székesföváros Idegenforgalmi Hivatalának 25 esztendös munkásságáról 1916-1941. Budapest Székesfőváros Idegenforgalmi Hivatala. Budapest.

Móritzné Gyenge A. - Probáld Á. [1981]: A nemzetközi idegenforgalom reprezentatív statisztikai megfigyelése. Statisztikai Szemle. 59. évf. 2. sz. 194-205. old.

NyITRAI, V. [1998]: The role of satellite accounts in the SNA. Hungarian Statistical Review. Special Number 2. pp. 11-16.

Országos IdEgENFORGalmi Hivatal [1965]: Az ENSZ nemzetközi utazási és idegenforgalmi konferenciája: Róma 1963. aug. 21. - szept. 5. Budapest.

PÁlos I. - TAKÁCs J. [1967]: Az idegenforgalmi adatgyüjtések elméleti és gyakorlati kérdései. Idegenforgalmi tanulmányok. 3. sz. Országos Idegenforgalmi Hivatal. Budapest.

PÁLOS I. [1971]: Korunk idegenforgalmának föbb jellemzői. Idegenforgalmi Közlemények. 3. sz. Országos Idegenforgalmi Hivatal. Budapest.

PÁLos I. [1975]: Az idegenforgalom statisztikai értékelésének módszertani kérdései. Statisztikai Szemle. 53. évf. 11. sz. 1117-1129. old.

Statisztikai Szemle, 96. évfolụam 6. szóm 610-640. oldal 
PenZ A. - ProbÁld Á. [1981]: A számok bűvöletében. Figyelö. XXV. évf. 34. sz. 2. old.

PROBÁld Á. - TAKÁCS J. [1977]: A nemzetközi idegenforgalom és a szállodai kapacitás. Statisztikai Szemle. 55. évf. 3. sz. 229-243. old.

PRoBÁLD Á. [1971]: A magyar idegenforgalmi kinálat versenyképességének vizsgálata. Doktori értekezés. Marx Károly Közgazdaságtudományi Egyetem. Budapest.

ProbÁld Á. [1973]: Néhány matematikai-statisztikai módszer alkalmazása a nemzetközi idegenforgalom statisztikai megfigyelésénél. Szakdolgozat. Marx Károly Közgazdaságtudományi Egyetem. Budapest.

ProBÁld Á. [1982]: A lakosság turisztikai mobilitása és annak várható alakulása. Városépítési Tudományos és Tervező Intézet. Budapest.

ProbÁld Á. [1983]: Utazási szokásaink. Figyelő. XXVII. évf. 14. sz. 7. old.

PRoBÁld Á. [2001]: Az idegenforgalmi statisztikai rendszer és a fejlesztés követelményei. Gazdaság és Statisztika. 13. (52.) évf. 6. sz. 68-77. old.

SÁRDI E. [1958]: Magyarország szállodái és üdülői. Statisztikai Szemle. 36. évf. 7. sz. 666-671. old.

SZÉKESFŐVÁROSI HÁZINYOMDA [1928]: Jelentés Budapest székesföváros Idegenforgalmi Hivatalának 1928. évi müködéséröl. Budapest.

TAKÁCs J. [1971]: A kereslet statisztikai mérési módszerei. Idegenforgalmi Közlemények. 3. sz. Országos Idegenforgalmi Hivatal. Budapest.

THIRRING G. [1927a]: Vidéki városaink és az idegenforgalom. Városok Lapja. XXII. évf. 15-16. sz. 143-145. old.

THIRRING G. [1927b]: A statisztika szerepe a városi igazgatásban. III. A statisztikai szolgálat szervezete. Városi Szemle: közlemények a városi közigazgatás és statisztika köréböl. 13. évf. 5. sz. 824-836. old.

THIRRING G. [1929]: Az idegenforgalmi statisztika problémái. Városok Lapja. XXIV. évf. 23. sz. 288-289. old.

UN (UNited NATIONS) - UNWTO (WoRld TOURISM ORganization) - EuRostat - OECD (ORGANISATION FOR ECONOMIC CO-OPERATION AND DEVELOPMENT) [2008]: Tourism Satellite Account: Recommended Methodological Framework 2008. Luxembourg, Madrid, New York, Paris. https://unstats.un.org/unsd/publication/seriesf/seriesf_80rev1e.pdf

WATERS, S. R. [1970]: Új megvilágításban a multiplikátorhatás a turisták pénzköltésének elemzésében. Idegenforgalmi Közlemények. 1-2. sz. Országos Idegenforgalmi Hivatal. Budapest.

\section{Summary}

Tourism has been present for decades in the economic and social history of Hungary. Since the middle of the $20^{\text {th }}$ century, it has played an increasingly important role not only in strengthening the development of the external economic sector, but also in improving the residents' quality of life, standard of living and the feeling of happiness. According to the government's tourism strategy adopted in September 2017, tourism will be one of the key areas of economy and well-being in the coming decades, and the statistics may contribute to this process by its own sources. The statistical generations of the future have to build on the decades of experience of tourism statisticians, the lessons of the past, and the accumulated knowledge capital. The study provides an overview of the 
long history of tourism statistics (border statistics, accommodation statistics, statistics of domestic tourism, etc.) from the beginnings through Hungary's EU accession to the present, focusing on the data collections and empirical studies of the Hungarian Central Statistical Office, and covering the activity of another actor of the official statistical service, the Ministry of Interior. 